Technical Paper

\title{
Adaptability of Wood Biomass to Fixed Bed Gasifier Controlling Bed Height
}

\author{
Hajime YASUdA ${ }^{*}{ }^{\dagger}$, Yoshizo SUZUKI ${ }^{* 1}$, Shohei SAKAI ${ }^{2}$, Takaaki WAJIMA ${ }^{* 2}$, and Hideki NAKAGOME*2 \\ (Received February 25, 2015)
}

For the biomass-to-liquid (BTL) process, pressurized gasification is an option in order to produce synthesis gas. Fixed bed gasification is promising as it results in relatively high conversion efficiencies as compared to other types of gasifiers on a smaller scale. Wood chips are adaptable feedstock for updraft fixed bed gasifiers. In considering whether to use waste materials or the use of powders for gasifiers, adaptability of the feedstock is a concern. For this study, a pressurized updraft fixed bed gasifier was chosen. The experimental setup comprised the gasifier, feedstock hopper, feeder, etc. inside a pressure vessel. Palm kernel shells (PKS) and wood pellets were used as feedstocks in this study. Although PKS is as adaptable feedstock as wood chips for updraft gasifiers, the adaptability of wood pellets, which are a kind of briquette biomass, has not been confirmed. As a result, good gasification was achieved with PKS, whereas problems such as channeling of the gas flow were caused using wood pellets. Such problems were reduced by lowering the bed height of the materials inside the gasifier, which increased the outlet gas temperature.

\section{Key Words}

Biomass, Gasification, Feedstock, Adaptability, BTL, DME

バイオマスをガス化し, DME 等の石油代替燃料を製造するBTL プロセスにおいて, ガス化ガスを DME に転換する工程は加 圧下で行われる。バイオマスのガス化を加圧で行えば，合成工程に送るガス化ガスの昇圧動力を低減することができる。アップドラ フト固定床方式では, 加圧ガス化を小規模でも高効率に行うことができる。固定床ガス化の原料には木質チップが適合する。廃棄 物系原料の使用を視野に入れると粉状や繊維状の原料の使用が課題となる。本研究では, 加圧容器の中に設置する固定床ガス 化炉で, 遠隔操作で着火・原料供給等を行える実験装置を設計・製作した。この装置を用い, 複数の原料を用いて試験を行った 結果, 原料により加圧固定床ガス化反応器に対する適合性に差違が見られた。原料として木質ぺレットを用いた試験ではガスの偏 流等の不具合を生じたのに対し，木質チップと同様に適合するパームカーネルシェルを用いた試験では良好なガス化反応を実現した。 木質ペレットで炉内原料層高を制御した実験を行ったところ, 層高を低くすると不具合は改善する一方, 出口ガス温度の上昇を招いた。 キーワード

バイオマス, ガス化, 原料, 適合性, BTL, DME

\section{Introduction}

Liquid fuels for transportation vehicles have been derived from petroleum. It is expected to obtain some fuels from sustainable materials in the future. A biomass-toliquid (BTL) process supplies fuels from biomass. The BTL process consists of biomass gasification and fuel synthesis. Dimethyl ether (DME) is one of the most applicable fuels

※ National Institute of Advanced Industrial Science and Technology (AIST)

16-1, Onogawa, Tsukuba, Ibaraki 305-8569, Japan

※2 Graduate School \& Faculty of Engineering, Chiba University 1-33 Yayoi-cho Inage-ku, Chiba-shi, Chiba 263-8522, Japan

$\uparrow \quad$ Corresponding author for diesel engines. DME can be obtained from synthesis gas (syngas; $\mathrm{CO}$ and $\mathrm{H}_{2}$ ), which can in turn be obtained by gasification of biomass. DME is synthesized usually at pressures of approximately 2-10 $\mathrm{MPa}$ with a catalyst ${ }^{1}$. In the BTL process, syngas has to be compressed by a booster machine to reach the pressure conditions required for the synthesis process. Because biomass is usually gasified at atmospheric pressure, syngas is usually obtained at atmospheric pressure. Therefore, 20-100 times compression is required for syngas through atmospheric pressure gasification to supply a synthesis process operating at 2-10 $\mathrm{MPa}$. 
Meanwhile, when biomass is gasified under pressurized conditions, the power needed for syngas compression can be reduced. Moreover, the height of a gasifier could be lowered theoretically by using pressurizing condition, because the linear velocity should be reduced at higher pressure compared to normal pressure with same mass flow rate. Nevertheless, the high gasification pressure needed for catalysis conditions is not suitable because plant costs such as the cost of materials will rise. According to Japanese legal regulations, "high pressure gas" is compressed gas whose pressure is not less than $1 \mathrm{MPa}$. Therefore, an appropriate pressurized condition for gasification seems to be less than $1 \mathrm{MPa}$. Considering a synthesis process that is operated at $2 \mathrm{MPa}$, two times compression of syngas is enough when the syngas is produced by gasification under $0.98 \mathrm{MPa}$. Recently, such lower pressure conditions as less than $1 \mathrm{MPa}$ were tried to apply DME catalytic synthesis ${ }^{2}$. Compression using booster machines will not be required when the synthesis process are operated at the same pressure level as the gasification process, i.e., at less than $1 \mathrm{MPa}$.

A fixed-bed gasifier was chosen as it has relatively high conversion efficiency as compared to other types of gasifiers such as entrained bed or fluidized bed on a smaller scale. A biomass gasification system with an updraft fixed bed gasifier with atmospheric pressure conditions has already been commercialized ${ }^{3)}{ }^{4}$. From an updraft gasifier, a significant amount of liquid products is obtained. Good-quality bio-oil can be obtained from such liquid products, thereby allowing it to be used as a substitute for petroleum4). Wood chips are an adaptable feedstock for updraft fixed bed gasifiers. When the amount of collectable biomass is limited in the area around a gasification plant, feedstock is desired in order to diversify from just wood chips to other unutilized biomass resources and waste materials. Considering the use of other feedstocks such as waste materials, adaptability to gasification is a concern. Inside the fixed bed gasifier, solid materials, comprising the biomass raw fuel material and partially reacted materials such as char, will move downward as the reaction progresses. Thus, a fixed bed gasifier is also called a moving bed gasifier. Usually, commercial updraft fixed bed gasifiers are not allowed to use powders or fibrous materials in order to ensure stable operation because such fibrous materials are anticipated to cause some problems ${ }^{5)} \sim 7$ ). In the case of gasifying shredded municipal refuse after gasifying wood chips, the quality of product gas deteriorated. Finally, operations were terminated as a result of channeling, which caused an increase in the temperature in the upper zone of the gasifier ${ }^{5}$. Channeling inside a fixed bed gasifier is a problem that occurs when gas escapes prematurely through undesired holes or voids among solid materials. Powders and fibrous materials commonly cause channeling. The flow and bridging characteristics of fibrous biomass have been tested to improve by mixing the fibrous biomass with wood chips. Even with $80 \%$ wood chips, the mixtures had a bridging tendency that was 3-5 times higher than that of pure (100\%) wood chips ${ }^{6}$. Airflow channeling occurred through the straw bed even before the initiation of gasification. The causes and solutions of the channeling problem have not been understood yet ${ }^{7}$. However, it was suggested that if the flowability needs to be improved, other concepts should be tried, e.g. upgrading to powders, briquettes, or pellets ${ }^{6}$.

Briquetting is a promising way to use various kinds and shapes of materials. Biomass could be fabricated into briquettes of a suitable size and shape to use for the updraft gasifier. However, the obtained briquettes might break inside the gasifier at high temperatures and with being surrounded by several gaseous substances. The adaptability of a briquetted material has to be confirmed in order to realize stable operation and to obtain the intended products. Pyrolysis experiments by Paulauskas et al. using single-pellet particles were tested in order to monitor the size change ${ }^{8}$. Polyanskii et al. reported on the strength of briquettes as a function of the particle size of the raw material powder and moisture content ${ }^{9}$. In the literatures, the influence of atmospheric conditions such as temperature and gaseous substances are not discussed. First, the adaptability of briquette biomass for fixed bed gasifiers has to be investigated, along with checking the product gas and the operation stability.

In this study, an experimental setup for pressurized fixed bed gasification was used. Wood pellets, which are a kind of briquette biomass, were used as the gasification feedstock to compare to the case of gasification using palm kernel shell (PKS). PKS is as suitable as wood chips for fixed-bed gasifiers. Moreover, PKS is more suitable than wood chips for screw feeders, which supply the feedstock to the gasifier continuously. The temperature inside the gasifier was monitored to check the real-time conditions during the experiment. Product gas distribution was monitored in order to evaluate the reaction and the adaptability of the raw materials. The materials inside the gasifier were observed after the reaction experiments were finished by quenching.

\section{Experimental}

\subsection{Apparatus and procedure}

A pressurized updraft fixed bed gasifier which operated below $1 \mathrm{MPa}$ gauge pressure was used. The whole 
apparatus, including gasifier, feedstock hopper, feeder, etc., were put inside a pressure vessel, as shown in Fig. 1. The feedstock was supplied continuously (10-80 g/min) from the hopper by the screw feeder. During stable operation, the supplying rate was kept to approximately $80 \mathrm{~g} / \mathrm{min}$. The feedstock was stacked by supporting it using a mesh plate as the bottom of the gasifier reaction zone. Air as the gasifying agent was supplied from the bottom of the gasifier at a rate of 10-100 L/min. During typical operation, air was supplied at a rate of $20 \mathrm{~L} / \mathrm{min}$ at the beginning of the experiment and gradually increasing it over 30$40 \mathrm{~min}$. During stable operation, the supply rate of the air was maintained at $100 \mathrm{~L} / \mathrm{min}$. The temperatures at five locations inside the gasifier were monitored by K-type thermocouples (TC) during each experiment. The distances from each TC to the bottom inside the gasifier were 10 mm (TC1), $50 \mathrm{~mm}$ (TC2), $115 \mathrm{~mm}$ (TC3), $460 \mathrm{~mm}$ (TC4), and $1008 \mathrm{~mm}$ (TC5). The product gas concentration was detected by gas chromatography with thermal conductivity detector (GC-TCD) and gas chromatography with flame ionization detector (GC-FID). Liquid products (tar and water solution) and residual solid products (char) were collected and weighed after the experiments.

Prior to the gasification experiment, the feedstock was stacked with the feeder at a height of 100-600 mm from the bottom inside the gasifier. Each experiment was started by electrically igniting the heater. After a few

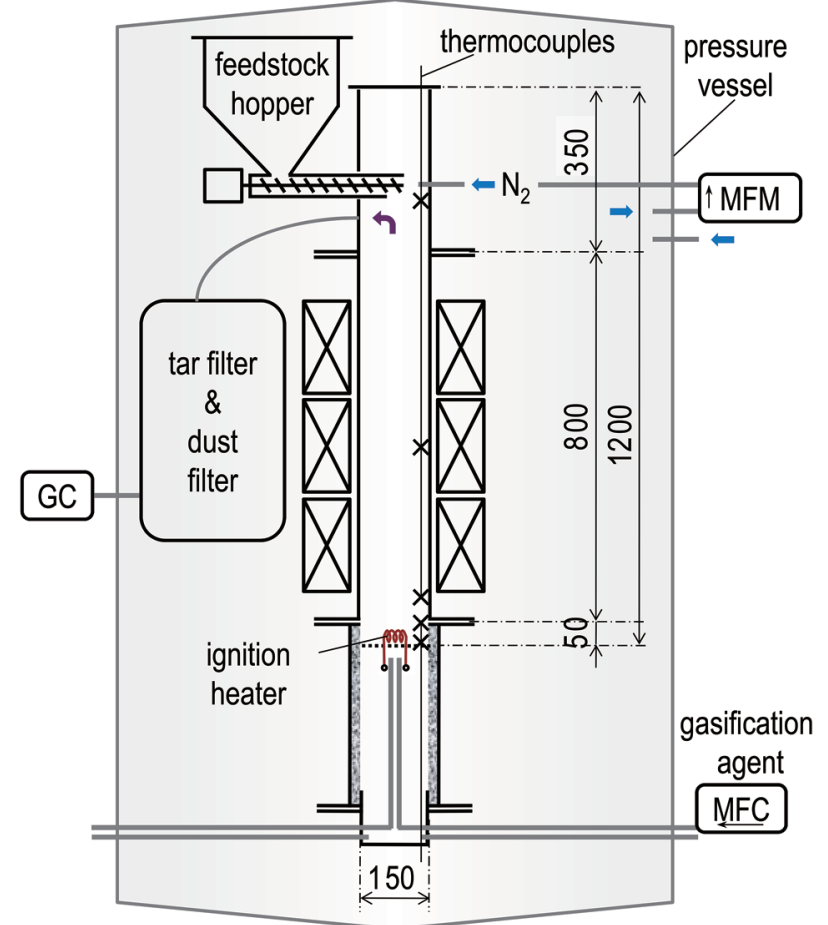

Fig. 1 Pressurized updraft fixed bed gasifier

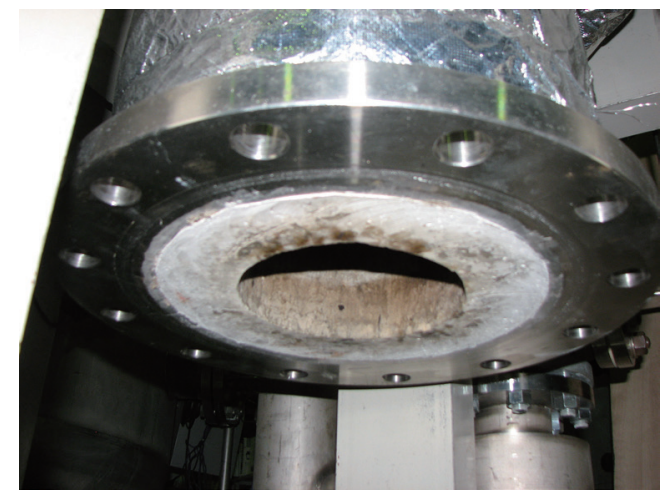

Fig. 2 Gasifier end flange

minutes, the heater was turned off after the TC1 and TC2 temperatures increased. During the experiments, the temperature change and gas concentration were continuously detected simultaneously. Each experiment was shut down by switching the gasifying agent from air to pure $\mathrm{N}_{2}$. The combustion and partial combustion were terminated and the temperature dropped gradually. Therefore, a certain amount of feedstock and char were left, which maintained the shutdown state inside the gasifier. After cooling the gasifier completely, the char state was observed by opening the flange at the bottom of the gasifier, removing the ignition heater, the support mesh plate, and the inlet gas tubes. Fig. 2 shows a photograph of the gasifier with the open-end flange. The liquid products were recovered from the tar pot, which was connected to the tar filter, and weighed.

\subsection{Feedstock}

PKS 3-25 $\mathrm{mm}$ in size and wood pellets (Japanese softwood) with diameters of $6 \mathrm{~mm}$ and lengths of 10 $25 \mathrm{~mm}$ were used. The proximate and ultimate analyses for the feedstocks are shown in Table 1. The maximum amount was $20 \mathrm{~kg}$ for an experiment. Both the wood pellets and PKS were well supplied to the gasifier by the feeder, and both materials retained their original shapes (i.e., not

Table 1 Analysis data of feedstocks

\begin{tabular}{lcc}
\hline & PKS & wood pellet \\
\hline \multicolumn{3}{c}{ proximate analysis (wt\%, dry basis) } \\
ash & 3.44 & 0.20 \\
volatile matter & 73.20 & 83.69 \\
fixed carbon & 23.36 & 16.11 \\
\multicolumn{1}{c}{ ultimate analysis (wt\%, dry ash free basis) } \\
carbon & 51.15 & 51.55 \\
hydrogen & 4.91 & 6.02 \\
nitrogen & 0.35 & 0.01 \\
oxygen (diff.) & 43.59 & 42.42 \\
\hline
\end{tabular}


broken) by just falling down onto the bottom of the gasifier. Both materials stacked at approximately $1 \mathrm{~cm} / \mathrm{min}$ inside the gasifier, with a regular supplying rate of approximately $80 \mathrm{~g} / \mathrm{min}$.

\section{Results and Discussion}

\subsection{PKS}

The temperatures change inside the gasifier during PKS gasification at $0.3 \mathrm{MPa}$ (gauge pressure) is shown in Fig. 3. The initial bed height for PKS was set to approximately $600 \mathrm{~mm}$. The temperatures at the lower part inside the gasifier, TC1-3, increased to approximately $500{ }^{\circ} \mathrm{C}$ approximately $20 \mathrm{~min}$ after ignition. TC2-3 remained over $500^{\circ} \mathrm{C}$ using $\mathrm{PKS}$, controlling the bed height of the materials inside the gasifier approximately 300-600 mm from the bottom. TC1 showed a decrease in the bottom temperature by ash deposition. At the same time, TC4 and TC5, which reflected the outlet gas temperature, remained below $250^{\circ} \mathrm{C}$.

Changes in the major product gas distribution are shown in Fig. 4. The product distribution was essentially constant after 60 min: $\mathrm{CO}: 50 \%, \mathrm{CO}_{2}: 20 \%, \mathrm{H}_{2}: 10 \%$, and $\mathrm{CH}_{4}$ :

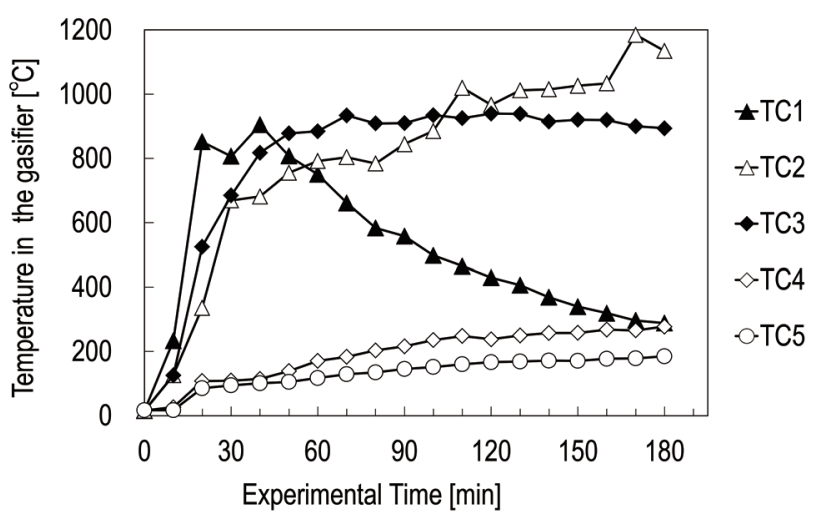

Fig. 3 Temperature changes inside gasifier during PKS gasification

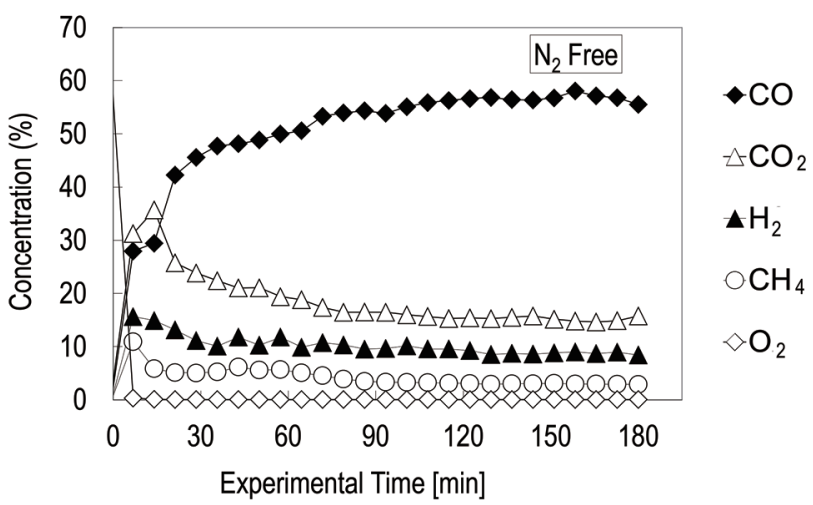

Fig. 4 Changes in product gas distribution during PKS gasification
$5 \%$. Similar changes in temperature and product distribution were observed and stable operation was maintained with changing experimental conditions such as pressure and bed height (100-600 mm), whereas the absolute values of the temperature and concentration varied.

After the experiments, the states of the char and inside the gasifier were observed, as shown in Fig. 5. Although some solid material attached to the inside wall is observed in Fig. 5a, most of it is slag formed by melting ash. Most of the char did not remain inside the gasifier; it moved downward smoothly and was collected after opening the end flange. Fig. 5b shows the collected char with keeping the state inside the gasifier. There is no notable heterogeneity of the residual solids in the planar direction, no large holes exceeding $10 \mathrm{~mm}$ in size, and no pulverization.

Gasification experiments were carried out with varying pressures at 0.1, 0.3, 0.5, and 0.7 MPa using PKS. Fig. 6 shows the yield of gas and liquid produced over each experiment. From the concentrations of gases, which were $\mathrm{H}_{2}, \mathrm{CO}, \mathrm{CO}_{2}, \mathrm{CH}_{4}, \mathrm{C}_{2} \mathrm{H}_{4}, \mathrm{C}_{2} \mathrm{H}_{6}, \mathrm{C}_{3} \mathrm{H}_{6}$, and $\mathrm{C}_{3} \mathrm{H}_{8}$, detected by $\mathrm{GC}$, the weight of each gas was calculated with integration over the period of the experiment. The gas yield was
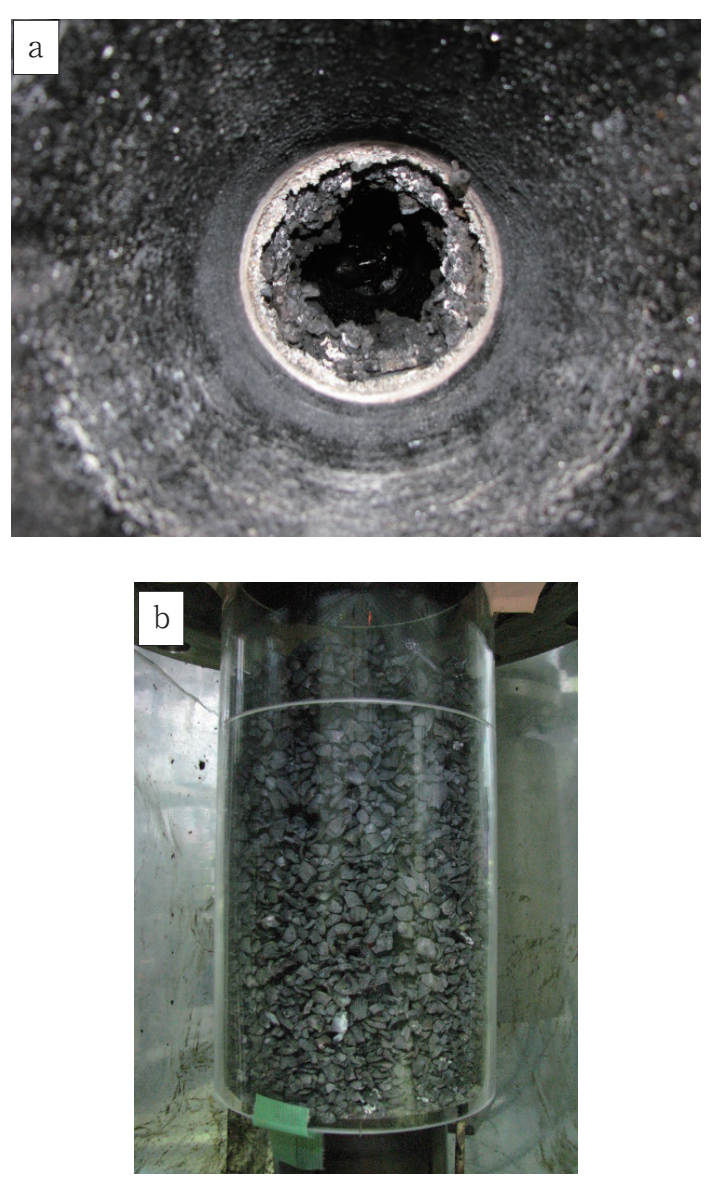

Fig. 5 Gasifier (a) inside and (b) char state after PKS gasification 


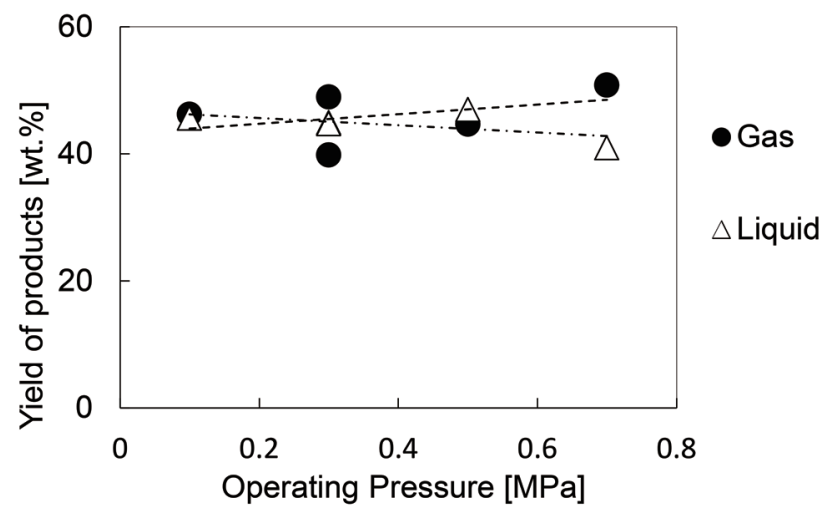

Fig. 6 Yield of gas and liquid from PKS gasification

obtained by combining their respective weights. The liquid yield was calculated from the liquid product weight. From the results in Fig. 6, the yield of both gas and liquid were 40-50 wt\% across the entire range of experimental pressures. Even though the tar yield decreased slightly with increasing pressure, no significant effect of the gasification pressure on the product yield was shown.

\subsection{Wood pellets}

Gasification experiments using wood pellets at $0.3 \mathrm{MPa}$ were carried out with an initial bed height of approximately $600 \mathrm{~mm}$. The air supply rate was $20 \mathrm{~L} / \mathrm{min}$ over the entire experiment because a stable gasification reaction could not be realized. Changes in major product gas distribution are shown in Fig. 7. Throughout the experiment, $\mathrm{CO}_{2}$ remained a major product. $\mathrm{CO}$ was near $30 \%$ at an early stage in the experiment, but it decreased monotonically to approximately $10 \%$ by the end of the experiment. Gasification to obtain syngas was not achieved by controlling the feeding rate, even by changing the oxygen concentration in the gasifying agent. $\mathrm{CO}_{2}$ remained as high as 40-60\% and CO did not exceed 20-30\% with a bed height of $300-600 \mathrm{~mm}$. It is suggested that a significant

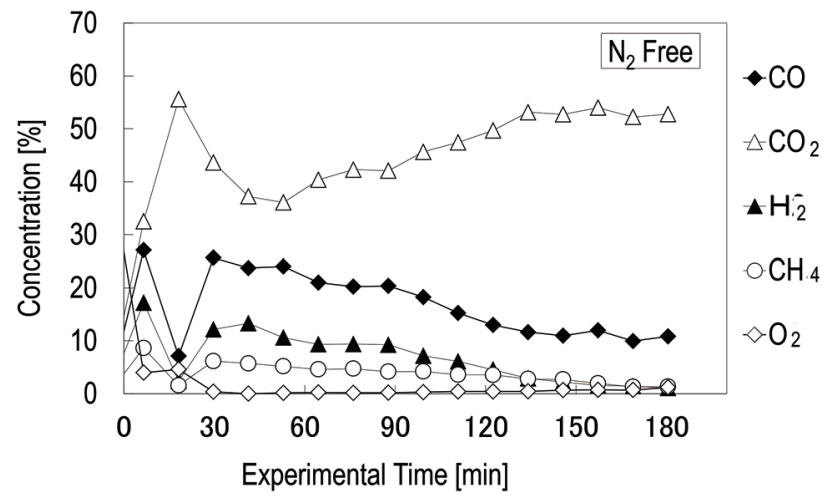

Fig. 7 Changes in product gas distribution during pellet gasification; initial bed height: $600 \mathrm{~mm}$
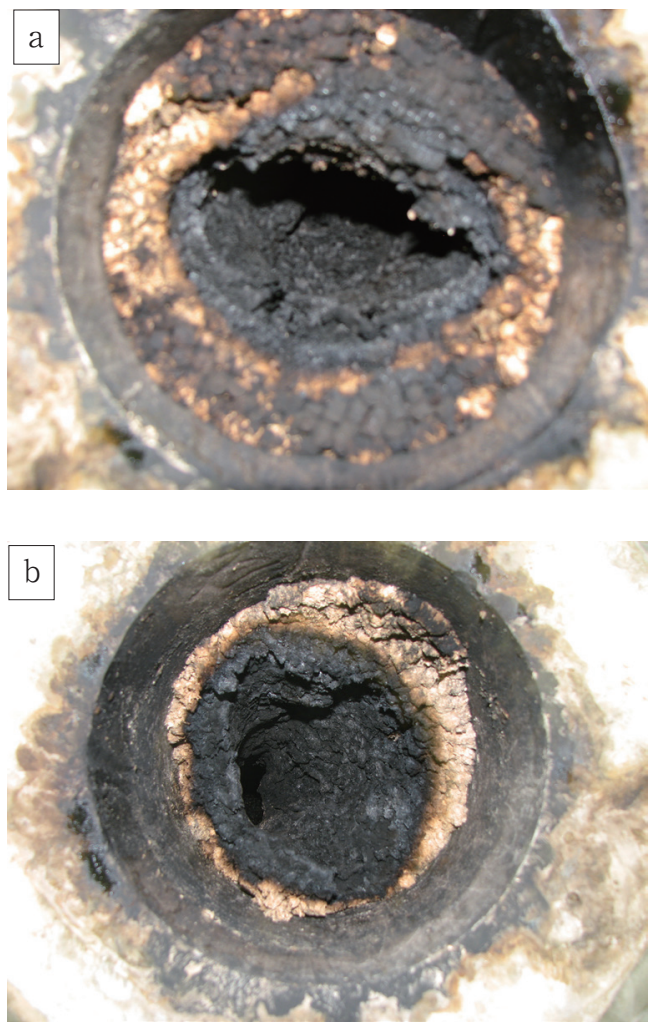

Fig. 8 Gasifier inside and char state after pellet gasification; initial height: $600 \mathrm{~mm}$; (a) bottom and (b) dug upward

amount of solids remained that could not be exposed to the high-temperature gas as a result of channeling from the high $\mathrm{CO}_{2}$ concentration.

After the experiments, wood pellets and associated char were found to have completely plugged the inside of the gasifier, as shown in Fig. 8. Almost no char materials dropped down, despite the lack of support when the bottom end flange was opened. There was a hole inside the material bed as a result of gas sweeping (channeling) caused by the accumulation of the materials, feedstock, and partially reacted char. Basically, several layers - the combustion zone, gasification zone, pyrolysis zone, and drying zoneare formed from the bottom up in a usual updraft gasifier. However, the layers seemed difficult to form because of the developing hole in the material bed. The combustion zone seemed to form on the surface of the channeling hole. This problem in the gas stream might be caused by pulverization and swelling of the wood pellets by exposure to vapors for several tens of minutes at $100-300^{\circ} \mathrm{C}$; the resulting powdery substance inhibited uniform gas flow. Briquetting did not prevent channeling in these conditions.

The bed height was then lowered to approximately 100-150 $\mathrm{mm}$ in order to prevent channeling formation. The temperatures changes inside the gasifier during wood pellet gasification at $0.3 \mathrm{MPa}$ are shown in Fig. 9. TC1 


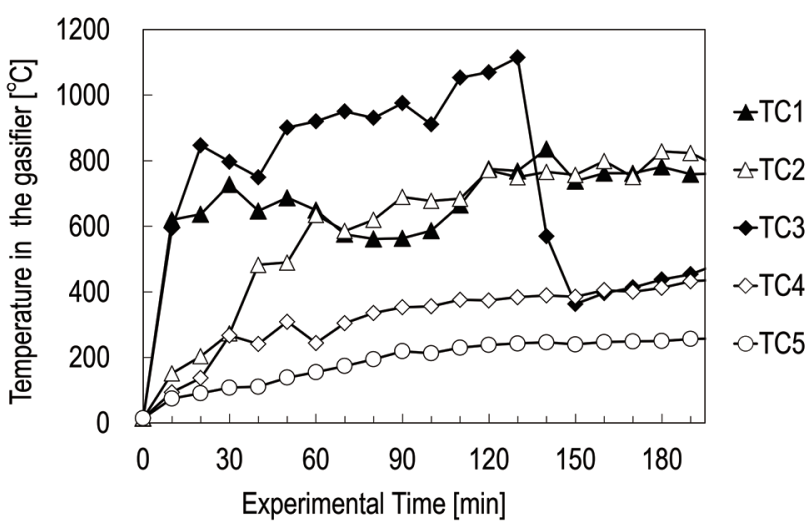

Fig. 9 Temperature changes inside gasifier during pellet gasification; initial bed height: $150 \mathrm{~mm}$

reached approximately $600{ }^{\circ} \mathrm{C}$ at 20 min after ignition and remained at $600-800{ }^{\circ} \mathrm{C}$. TC2 reached approximately $600^{\circ} \mathrm{C}$ at $60 \mathrm{~min}$. Meanwhile, TC3 reached approximately $800{ }^{\circ} \mathrm{C}$ at $10 \mathrm{~min}$, and it continued to increase toward $1100{ }^{\circ} \mathrm{C}$ at $120 \mathrm{~min}$. It then decreased to approximately $300^{\circ} \mathrm{C}$ after 130 min because TC3 was placed near the top of the material bed. The bed height seemed to fluctuate depending on the consumption rate of the feedstock. Although combustion was the major reaction in the early stage of the experiment, gasification became major in the latter half, lowering the top of the bed under TC3. Gasification at the same air supply rate induced a higher consumption rate than combustion. TC4, which reflected the outlet gas temperature, exceeded $250^{\circ} \mathrm{C}$ in a matter of $30 \mathrm{~min}$, continued to increase toward $400^{\circ} \mathrm{C}$ at $200 \mathrm{~min}$. The outlet gas temperature was higher $\left(>400^{\circ} \mathrm{C}\right)$ when the bed height was lower $(<150 \mathrm{~mm})$ as compared with the results for PKS, in which the temperature was lower $\left(<250^{\circ} \mathrm{C}\right)$ at higher bed heights $(300-600 \mathrm{~mm})$. Changes in the major product gas distribution are shown in Fig. 10. $\mathrm{CO}_{2}$ was again the major product, with leading by combustion until $40 \mathrm{~min}$. After the concentrations of the product gases fluctuated up and down for approximately 40-90 min, CO exceeded 50\% after 90 min, migrating to gasification as the major reaction, which continued up to $200 \mathrm{~min}$. Looking inside at the gasifier after the experiments, there were little residue inside, as shown in Fig. 11a. Most of the residual char was collected when the bottom end flange was opened. The state of the char is as shown in Fig. 11b. Even though some of char particles are attached to each other, there seemed to be no large holes exceeding $10 \mathrm{~mm}$ in size. The trouble shown when the bed height was 300-600 seems to be resolved mostly by controlling the bed height to $100-150 \mathrm{~mm}$. However, the temperature increase causing heavier tar formation has to be considered as well. Wood pellets were found to be a sensitive feedstock in terms of adaptability for fixed-bed

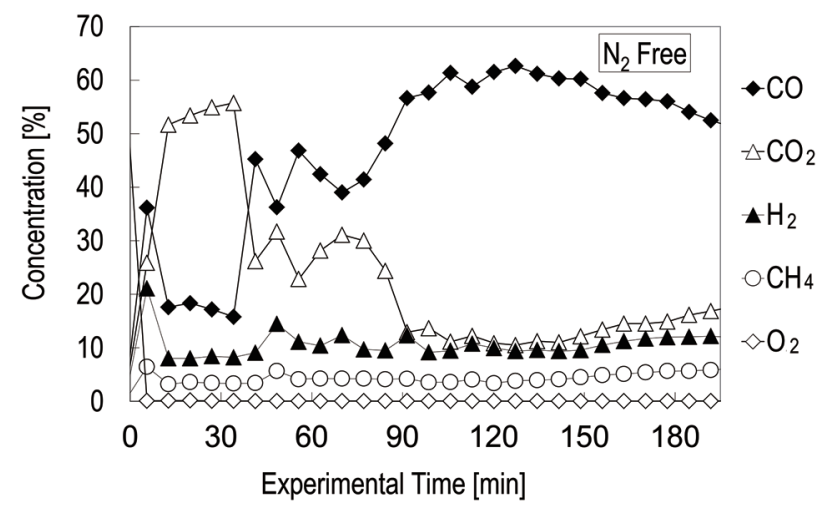

Fig. 10 Changes in product gas distribution during pellet gasification; initial bed height: $150 \mathrm{~mm}$
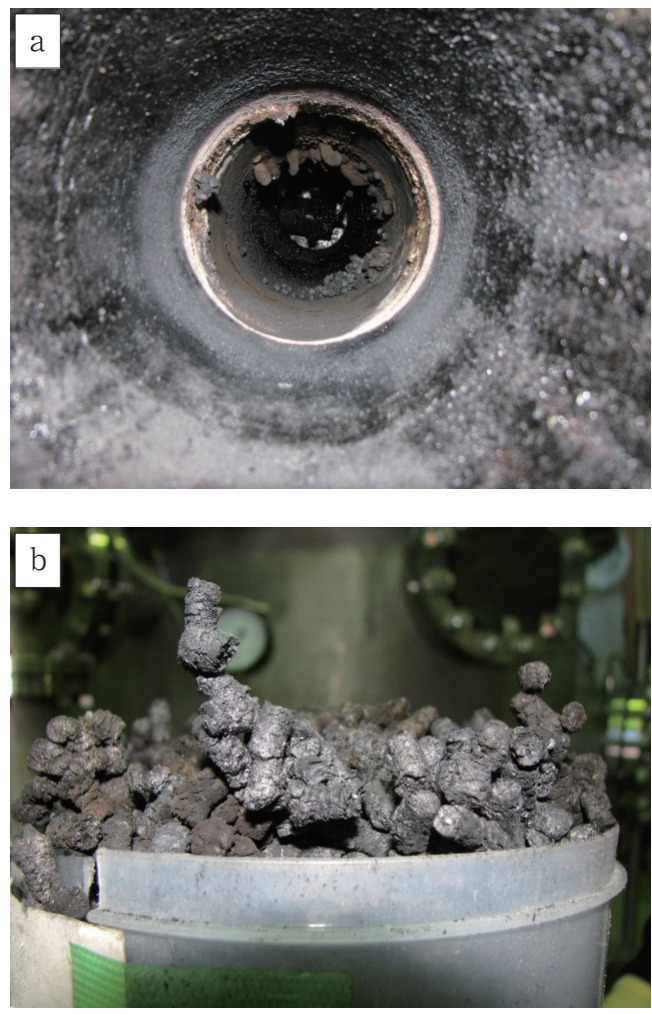

Fig. 11 Gasifier (a) inside and (b) char state after pellet gasification; initial height: $150 \mathrm{~mm}$

gasifiers.

From these results, it was found that channeling inside an updraft gasifier could easily occur by using wood pellets, a kind of briquetted biomass. Even though wood pellets were not broken, retaining their original shapes after falling to the bottom of the gasifier, they easily fall apart, returning to powder when exposed to vapors for several tens of minutes at $100-300^{\circ} \mathrm{C}$ inside the gasifier. In contrast, PKS retained the original shape inside the gasifier until just before finishing the reaction. It could be said that briquetting had a limited effect from the results obtained when the height was $100-150 \mathrm{~mm}$ with the wood pellets. In 
this condition, the wood pellets were consumed in 10-15 min when stable gasification was achieved. It is suggested that because as the wood pellets might not be back to powder within several minutes until their consumption, channeling could be avoided by controlling the bed height. Nevertheless, in the initial stage of the experiment with the lower bed height with wood pellets, the gasification reaction did not progress for $30 \mathrm{~min}$ or more. Also, the temperature increased undesirably, causing heavier tar formation. In this study, wood pellets were used initially as a typical briquetting biomass. The wood pellets were found to have less strength in terms of keeping their original shape to oppose the surrounding substance inside the gasifier. The strength to resist the atmosphere has to be improved in order to use briquettes for the gasifier. The factors affecting dissolution of the wood pellets back to powder are not clear from the results. Further study is required to clarify these factors. Wood pellets might be pulverized and swollen by exposure to vapors such as water present in the gasifier.

\section{Conclusions}

The pressurized fixed-bed gasification of PKS and wood pellets was carried out. Even though the tar yield decreased slightly with pressure, no significant effect of the gasification pressure on the product yield was shown. The difference between PKS and the wood pellets was seen in their respective adaptabilities for pressurized fixed bed gasification. Good gasification was achieved in the experiment for PKS, whereas problems such as the channeling of the gas flow were caused using wood pellets. Such problems were reduced by lowering the bed height of the materials inside the gasifier, even though outlet gas temperature increased.

\section{References}

1) Wang, T.; Wang, J.; Jin, Y., Ind. Eng. Chem. Res., 46, 5824 (2007)

2) Miyazawa, T.; Matsunaga, K.; Hanaoka, T.; Sakanishi, K.; Ogawa, T., J. Jpn. Inst. Energy, 88, 918 (2009)

3) Ahrenfeldt, J.; Thomsen, T. P.; Henriksen, U.; Clausen, L. R., Appl. Therm. Eng., 50, 1407 (2013)

4) Okuyama, K.; Miyagoshi, Y.; Suzuki, Y.; Iwasaki, T., J. Jpn. Inst. Energy, 91, 1047 (2012)

5) Mudge, L. K.; Rohrmann, C. A., ACS Symp. Ser., 76, Solid Wastes and Residues, Chapter 7, 126 (1978)

6) Mattson, J. E., Biomass Bioenergy, 12, 199 (1997)

7) Tarhan, S., Energy Sources, 25, 1183 (2003)

8) Paulauskas, R.; Džiugys, A.; Striugas, N., Fuel, 142, 145 (2015)

9) Polyanskii, L. I.; Puzanov, A. P.; Kobelev, V. A., Refract. Ind. Ceram., 48, 111 (2007) 